\title{
Performance and egg quality of Embrapa 051 laying hens subjected to different feeding programs
}

\author{
[Desempenho e qualidade de ovos de poedeiras da linhagem Embrapa 051 submetidas a diferentes \\ programas alimentares]
}

\section{"Artigo Científico/Scientific Article"}

\author{
Suelen Nunes da Silva ${ }^{*}$, Juliana Forgiarini' ${ }^{1}$, Débora Aline Alves ${ }^{1}$, Everton Luis Krabbe ${ }^{2}$, \\ Valdir Silveira Avila² ${ }^{2}$ Débora Cristina Nichelle Lopes $^{3}$, Eduardo Gonçalves Xavier ${ }^{3}$
}

\author{
${ }^{1}$ Federal University of Pelotas, Pelotas-RS, Brazil. \\ ${ }^{2}$ Embrapa Swine and Poultry, Concordia-SC, Brazil \\ ${ }^{3}$ Department of Animal Science, Federal University of Pelotas-RS, Brazil. \\ *Autor para correspondência/Corresponding author: E-mail: suelennunesdasilva@ hotmail.com
}

\begin{abstract}
This study aimed to evaluate the productive performance and egg quality of Embrapa 051 lineage laying hens compared to a commercial line (Lohmann Brown) when subjected to different feeding programs. Trial consisted of a randomized complete block design, with four treatments: T1 - Lohmann Brown Line receiving 100\% basal diet; T2 - Embrapa 051 Line receiving 93\% basal diet; T3 - Embrapa 051 line receiving 100\% basal diet; and T4 - Embrapa 051 lineage receiving 107\% basal diet. The treatments had five replicates each. The basal diet was that recommended by the Lohmann Brown line manual. Variables of bird performance (egg weight, egg production rate, feed conversion per dozen eggs, energy conversion and egg mass) were analyzed, as well as internal egg quality (Haugh unit, yolk color, yolk percentage, and albumen percentage) and external egg quality (specific gravity, shell percentage, and shell thickness). All performance variables presented significant differences $(\mathrm{P}<0.05)$ in the three evaluated cycles, comparing lineages. Egg produced by the Embrapa 051 line had the highest percentages of yolk and those of the Lohmann Brown line had the highest percentage of albumen. In conclusion, Embrapa 051 lineage has the potential to produce good quality eggs, as long as it receives the same feeding program of the genetically established lineage.

Keywords: external quality; internal quality; Lohmann Brown; productive performance.
\end{abstract}

\section{Resumo}

O objetivo deste estudo foi avaliar o desempenho produtivo e a qualidade dos ovos da poedeira Embrapa 051, em comparação com uma linhagem comercial (Lohmann Brown), sujeita a diferentes programas alimentares. O delineamento experimental utilizado foi o de blocos completamente casualizados, e os tratamentos foram: T1 - Linhagem Lohmann Brown recebendo 100\% da dieta base; T2 - Linhagem Embrapa 051 recebendo 93\% da dieta base; T3 - Linhagem Embrapa 051 recebendo 100\% da dieta base; e T4 - Linhagem Embrapa 051 recebendo $107 \%$ da dieta base. Os tratamentos tiveram cinco repetições cada. A dieta base foi a recomendada pelo manual da linhagem Lohmann Brown. Foram analisadas variáveis de desempenho zootécnico (peso dos ovos, taxa de produção de ovos, conversão alimentar por dúzia de ovo, conversão energética e massa de ovo); qualidade interna (unidade Haugh, coloração da gema, porcentagem de gema e porcentagem de albúmen) e qualidade externa de ovos (gravidade específica, porcentagem de casca e espessura de casca). Todas as variáveis de desempenho apresentaram diferenças significativas $(\mathrm{P}<0,05)$ nos três ciclos avaliados, sendo que as aves da linhagem Lohmann Brown apresentaram os maiores valores para essas variáveis. Em relação às variáveis de qualidade interna e externa dos ovos, apenas as porcentagens de gema e de albúmen apresentaram diferença significativa $(\mathrm{P}<0,05)$ entre os tratamentos nos três ciclos avaliados. Os ovos produzidos pela linhagem Embrapa 051 apresentaram as maiores porcentagens de gema e os da linhagem Lohmann Brown a 
maior porcentagem de albúmen. Com o presente trabalho pode-se concluir que a linhagem Embrapa 051 tem potencial para produzir ovos de boa qualidade, desde que receba o mesmo programa alimentar da linhagem geneticamente estabelecida.

Palavras-chave: desempenho zootécnico; Lohmann Brown; qualidade externa; qualidade interna.

\section{Introduction}

Egg is a natural and complete food, with the advantage of having an affordable price for consumers. It has a high protein content of excellent quality, including lipids, vitamins, minerals, and antioxidants. All these components give the egg modulating characteristics of the immune system, thus reinforcing the importance of its consumption in the prevention and treatment of diseases (Mazzuco, 2008).

According to the Brazilian Association of Animal Protein (ABPA), in 2015, Brazil produced a total of 39.5 billion egg units, $6.1 \%$ more than in the previous year, reaching a historical record. Per capita consumption also increased from 182 eggs in 2014 to 191.7 units in 2015, as a result of the intensification of the pro-consumption campaigns, which aim to demystify nutritional questions about egg (ABPA, 2016).

Most of the egg production in Brazil is performed in the conventional way, that is, highly intensive, with hens raised in cages. However, the high demand by consumers for differentiated and superior products has been influencing changes in the systems. Society is interested in production systems that prioritize welfare in animal husbandry, are environmentally friendly, and have sustainability characteristics.

The semi-intensive system is indicated for those who wish to have a flock with health control and respecting the space that the bird needs to live and develop. Although the bird has access to a free area to circulate, it is delimited, which allows full productive, nutritional, and sanitary control. In Brazil, eggs produced under these conditions are called free-range or colonial.

Free-range eggs are produced under less rigid conditions than organic ones and therefore have lower production costs and lower selling prices. As this product has a lower cost of production and is well accepted in the market, there are more producers that decide to invest in this production system. Hens of the Embrapa 051 line are highly sought after by Brazilian producers for this activity, as they are dual purpose birds and can be slaughtered and consumed at the end of the productive cycle.

In view of the above mentioned facts, this study aimed to evaluate the productive performance and egg quality of Embrapa 051 laying hens subjected to different feeding programs and reared in a semi-intensive system, aiming at an improved welfare condition.

\section{Material and Methods}

A total of 800 laying hens were used, of which 600 were birds of the Embrapa line 051 and 200 of the commercial Lohmann Brown line. The experimental period was 25 to 36 weeks of age, totaling three productive periods of 28 days each, totaling 84 days.

Hens were housed in a wooden shed, divided into 20 floor pens and each pen contained a small door that gave access to an external paddock. In each box there was a perch and a wooden nest with eight openings each, lined with shavings. A pendular feeder and another plate feeder for grass, both manual, and nipple systems were used.

Four treatments were tested that differed by the amount of feed received by birds, and the basic adopted feeding program was recommended by the Lohmann Brown line management guide (Lohmann do Brasil, 2011). Treatment 1 (T1) was composed of birds of the Lohmann Brown commercial line receiving the basal diet $(100 \%)$; treatment 2 (T2), birds of the Embrapa 051 line receiving $93 \%$ of the basal diet; treatment 3 (T3), birds of the Embrapa 051 line receiving the same amount of the basal diet (100\%); and treatment 4 (T4), birds of the Embrapa 051 line receiving 107\% of the basal diet. The treatments are presented in Table 1.

Two experimental diets were used, which were based on the nutritional requirements of the Lohmann Brown line (Lohmann do Brasil, 2011). From 25 to 28 weeks, a pre-laying diet was used and from the $29^{\text {th }}$ to $36^{\text {th }}$ week, a laying diet, both described in Table 2. Each bird also received $30 \mathrm{~g}$ of bulky food per day (dwarf elephant grass Pennisetum purpureum Schum. cv. Mott). 
Table 1. Experimental treatments description.

\begin{tabular}{cccc}
\hline Treatment & Line/Breed & Feed intake $(\mathrm{g} /$ bird/day $)$ & Relative FI* $(\%)$ \\
\hline 1 & Lohmann Brown & 114 & 100 \\
2 & Embrapa 051 & 106 & 93 \\
3 & Embrapa 051 & 114 & 100 \\
4 & Embrapa 051 & 122 & 107 \\
\hline
\end{tabular}

*FI: Feed intake. T1: Lohmann Brown commercial line + basal diet (100\%); T2: Embrapa 051 line + 93\% basal diet; T3: Embrapa 051 line + basal diet (100\%); T4: Embrapa 051 line $+107 \%$ basal diet. CV: coefficient of variation. P: probability. Means followed by different letters in the same row are significantly different by Tukey's test $(\mathrm{P}<0.01)$.

Table 2. Composition of experimental diets.

\begin{tabular}{|c|c|c|}
\hline Ingredients & Pre-laying (\%) & Laying (\%) \\
\hline Corn grain & 55.00 & 60.00 \\
\hline Soybean meal $-45 \%$ crude protein & 28.62 & 16.08 \\
\hline Wheat bran & 5.55 & 13.26 \\
\hline Limestone & 8.70 & 9.37 \\
\hline Common salt & 0.38 & 0.43 \\
\hline Vitamin and Mineral Supplement ${ }^{1}$ & 0.40 & 0.40 \\
\hline Soybean oil & 1.21 & 0.33 \\
\hline Mycotoxin Binder $^{2}$ & 0.10 & 0.10 \\
\hline L-lysine & - & 0.05 \\
\hline DL-methionine & - & 0.05 \\
\hline BHT & 0.01 & 0.01 \\
\hline Phytase $^{3}$ & 0.01 & 0.01 \\
\hline L-tryptophan & - & 0.0052 \\
\hline L-threonine & - & 0.0002 \\
\hline TOTAL & & 100 \\
\hline \multicolumn{3}{|l|}{ Nutritional composition calculated } \\
\hline Metabolizable energy, Mcal/kg & 2.80 & 2.75 \\
\hline Crude protein, \% & 18.00 & 13.96 \\
\hline Crude fiber, $\%$ & 2.99 & 3.15 \\
\hline Calcium, \% & 3.70 & 3.90 \\
\hline Sodium, \% & 0.16 & 0.18 \\
\hline Linoleic acid, \% & 2.06 & 1.74 \\
\hline Available phosphorus, $\%$ & 0.51 & 0.50 \\
\hline Total phosphorus, $\%$ & 0.76 & 0.77 \\
\hline Fat, \% & 3.89 & 3.25 \\
\hline Digestible Methionine, \% & 0.33 & 0.33 \\
\hline Digestible Methionine + cystine, $\%$ & 0.61 & 0.57 \\
\hline Digestible Lysine, \% & 0.84 & 0.62 \\
\hline Digestible Threonine, $\%$ & 0.60 & 0.45 \\
\hline Digestible Tryptophan, \% & 0.20 & 0.15 \\
\hline Digestible Arginine, $\%$ & 0.80 & 0.80 \\
\hline Digestable Isoleucine, $\%$ & 0.68 & 0.49 \\
\hline Digestible Valine, $\%$ & 0.78 & 0.59 \\
\hline
\end{tabular}

At the end of each 28-day cycle, all birds were weighed individually pen. On the same day, a dozen eggs per replicate was separated for internal and external quality analyses.

Before broken, the eggs were weighed individually on a digital scale (accuracy $0.01 \mathrm{~g}$ ). The rate of egg production, measured as a percentage $(\%)$, was calculated by $P(\%)=$ $(O P P * 100) / Y$, in which $\mathrm{P}(\%)$ is the laying rate;
OPP is the total number of eggs produced in the period, and $\mathrm{Y}$ is the number of days in the period. To obtain this data, the daily production was recorded.

The feed conversion ratio per dozen eggs (FCRDE) was determined by FCRDE = total feed consumption $(\mathrm{kg}) /$ number ofdozens. Energy conversion was calculated using the formula Conv.energ $=$ 
calories (ingested)/grams of egg. Egg mass was calculated by the formula Egg mass = $A E W *$ laying rate $/ 100$, where AEW means average egg weight.

Eggs were taken to a laboratory where internal and external quality analyses were performed. Eggs were carefully opened and placed individually on Petri dishes where the albumen height was measured with a digital caliper accurate to $0.01 \mathrm{~mm}$. This measurement, together with the weight of the egg, was used for the calculation of the Haugh unit, with the formula $U H=$ $100 \log \left(h+7.57-1.7 w^{0.37}\right)$, where $h$ is the height of the albumen in millimeters, and $w$ is the weight of the egg, in grams.

With the egg still on the Petri dish, the color of the yolk was evaluated using the DSM $^{\circledR}$ colorimetric fan, which assigns colors to scores ranging from 1 to 15 , in shades of yellow and orange. Color analysis was also performed using a digital colorimeter Konica Minolta ${ }^{\circledR}$. Two measurements were taken from each yolk and, thereafter, an arithmetic mean was calculated with the two values. The parameters measured by the digital colorimeter were those of CIEL (International Commission of L'Eclairage): L * (luminosity), $\mathrm{a}^{*}$ (red/green coordinate) and $\mathrm{b}^{*}$ (yellow/blue coordinate). Using the parameters $a^{*}$ and $\mathrm{b}^{*}$, it was possible to make a relationship and obtain the parameter $C^{*}$ (chroma), which measures the color saturation, through the formula $C *=$ $\left[(a *)^{2}+(b *)^{2}\right]^{1 / 2}$ (McLaren, 1976).

After the color analysis, yolk and albumen were separated with a separator. The albumens were discarded and the yolks were weighed individually on a digital scale accurate to $0.01 \mathrm{~g}$. With the weight obtained, in grams, the percentage of yolk of each egg was calculated with the formula $\% Y=($ yolk weight/egg weight) $* 100 . \quad$ The albumen weight, in grams, was obtained by calculating the difference between the total egg weight and the shell and yolk weights, using the formula albumen weight $=$ egg weight yolk weight - shell weight. With the weight in grams, it was possible to calculate the albumen percentage of each egg using the formula \%albumen $=$ (albumen weight $/$

egg weight) $* 100$.

After being weighed, the yolks were placed on another Petri dish and measured for diameter $(\mathrm{mm})$ and height $(\mathrm{mm})$ with a digital caliper accurate to $0.01 \mathrm{~mm}$. The yolk index (YI) value obtained by the ratio between these two measurements, using the formula $Y I=$ yolk height/yolk diameter.

Among the variables of external quality of eggs that were analyzed is the specific gravity, measured by the method explained by Zumbado (1983): all the eggs were placed in buckets with saline solutions, from lower to higher concentration of sodium chloride $(\mathrm{NaCl})$, ranging from 1.066 to 1.102 , with an interval of 0.004 , totaling 10 solutions. The eggs were removed as they floated, thus recording the respective density value corresponding to the solution of the bucket.

The shell percentage was determined after all analyses were performed on the eggs. Shells were washed with tap water and dried at room temperature for 72 hours, according to Barbosa et al. (2012), when they were individually weighed on a digital scale (accuracy 0.01g).

After weighed, a shell fragment was taken from three regions of the egg (basal, apical and medial). Each fragment was measured using an analytical micrometer with accuracy of $0.01 \mathrm{~mm}$. To obtain the final value of shell thickness, an arithmetic mean was calculated with the three values obtained, according to Barbosa et al. (2012).

Birds were distributed in a randomized block design, in which the initial weight was the blocking factor. Four treatments were tested with five replicates each, the experimental unit was formed by each of the pens containing 40 birds.

Data were submitted to variance analysis, through the Statistix ${ }^{\mathrm{TM}}$ software (2008). Means were submitted to the Tukey test, protected by the overall F-test $(\mathrm{p} \leq 0.05)$. The statistical model used was expressed by the formula $Y_{i j}=\mu+T i+$ $B j+e_{i j}$, where $\mathrm{Y}_{\mathrm{ij}}=$ response variable; $\mu=$ total mean; $\mathrm{Ti}=$ treatment effect; $\mathrm{Bj}=$ block effect; $\mathrm{e}_{\mathrm{ij}}=$ random error.

\section{Results and Discussion}

All performance variables presented significant difference $(\mathrm{P}<0.05)$. The means obtained for each variable as well as the coefficients of variation and probability, divided by productive cycle, are listed in Table 3.

The body weight of the animals followed the natural tendency of the lines, since Lohmann Brown (T1) weighed less than Embrapa 051. This response was observed in all cycles.

Hens of the Lohmann Brown line (T1) produced heavier eggs in all evaluated cycles ( $\mathrm{P}$ $<0.05)$. On the other hand, those of the Embrapa 051 line that received $93 \%$ basal diet produced the 
lightest eggs $(\mathrm{P}<0.05)$, probably due to lower feed intake and, consequently, lower nutrient intake. Similarly, Wu et al. (2008) also observed a decrease in egg weight of birds receiving less nutrients in their diets. However, the birds of the same line, receiving $100 \%$ and $107 \%$ basal diet (T3 and $\mathrm{T} 4$, respectively) did not differ in egg weight $(\mathrm{P}>0.05)$ in any of the cycles, which suggests that there is no need to increase the amount of feed beyond that recommended for the Lohmann Brown line, taking into account this variable, even though Embrapa 051 is a heavier hen.

Table 3. Performance of two laying breeds (E - Embrapa 051 and L - Lohmann Brown) subjected to different feeding programs during three productive cycles.

\begin{tabular}{|c|c|c|c|c|c|c|}
\hline \multirow[b]{2}{*}{ Variables } & \multicolumn{6}{|c|}{ 1st cycle (25 - 28 weeks) } \\
\hline & T1 - L100 & T2-E93 & T3- E100 & T4-E107 & CV (\%) & $\mathbf{P}$ \\
\hline $\mathrm{BW}(\mathrm{g})$ & $1954.2 b$ & $2104.6 \mathrm{a}$ & $2146.8 \mathrm{a}$ & $2136.2 \mathrm{a}$ & 5.63 & 0.0056 \\
\hline EW (g) & $60.21 \mathrm{a}$ & $52.33 \mathrm{c}$ & $54.04 \mathrm{~b}$ & $53.86 \mathrm{~b}$ & 6.88 & $<0.00001$ \\
\hline$\%$ Laying & $94.24 \mathrm{a}$ & $85.03 b$ & $87.08 b$ & $86.50 \mathrm{~b}$ & 6.85 & $<0.00001$ \\
\hline $\mathrm{EC}$ (cal/g egg) & $53.04 d$ & $56.74 \mathrm{c}$ & $59.09 b$ & $63.77 \mathrm{a}$ & 7.12 & $<0.00001$ \\
\hline EM (g/bird/day) & $56.73 \mathrm{a}$ & $47.08 b$ & $48.72 b$ & $49.11 b$ & 8.06 & $<0.00001$ \\
\hline \multirow[t]{2}{*}{ FCRDE (kg/dz) } & $1.452 \mathrm{c}$ & $1.505 \mathrm{bc}$ & $1.574 b$ & $1.700 \mathrm{a}$ & 8.52 & $<0.00001$ \\
\hline & \multicolumn{6}{|c|}{ 2nd cycle (29 - 32 weeks) } \\
\hline $\mathrm{BW}(\mathrm{g})$ & $2004.8 c$ & $2083.9 b$ & $2155.8 \mathrm{a}$ & $2177.4 \mathrm{a}$ & 5.19 & $<0.00001$ \\
\hline EW (g) & $59.91 \mathrm{a}$ & $52.38 \mathrm{c}$ & $54.62 b$ & $54.86 b$ & 7.04 & $<0.00001$ \\
\hline$\%$ Laying & $93.76 \mathrm{a}$ & $87.05 \mathrm{c}$ & $88.48 \mathrm{bc}$ & $89.87 b$ & 4.29 & $<0.00001$ \\
\hline $\mathrm{EC}$ (cal/g egg) & $59.90 \mathrm{a}$ & $52.38 \mathrm{c}$ & $54.62 b$ & $54.86 b$ & 5.63 & $<0.00001$ \\
\hline EM (g/bird/day) & $56.02 \mathrm{a}$ & $44.89 \mathrm{c}$ & $47.86 b$ & $48.38 b$ & 9.02 & $<0.00001$ \\
\hline \multirow[t]{2}{*}{ FCRDE $(\mathrm{kg} / \mathrm{dz})$} & $1.463 \mathrm{c}$ & $1.464 \mathrm{c}$ & $1.546 \mathrm{~b}$ & $1.630 \mathrm{a}$ & 5.61 & $<0.00001$ \\
\hline & \multicolumn{6}{|c|}{ 3rd cycle (33 - 36 weeks) } \\
\hline $\mathrm{BW}(\mathrm{g})$ & $1992.8 \mathrm{c}$ & $2099.2 b$ & $2154.6 \mathrm{a}$ & $2207.8 \mathrm{a}$ & 4.92 & $<0.00001$ \\
\hline EW (g) & $59.22 \mathrm{a}$ & $53.40 \mathrm{c}$ & $55.71 b$ & $55.73 b$ & 5.86 & $<0.00001$ \\
\hline \% Laying & $94.88 \mathrm{a}$ & $79.21 \mathrm{c}$ & $86.94 b$ & $89.50 \mathrm{~b}$ & 7.51 & $<0.00001$ \\
\hline $\mathrm{EC}(\mathrm{cal} / \mathrm{g}$ egg) & $59.22 \mathrm{a}$ & $53.40 \mathrm{c}$ & $55.71 \mathrm{~b}$ & $55.57 b$ & 4.30 & $<0.00001$ \\
\hline EM (g/bird/day) & $55.38 \mathrm{a}$ & $40.48 \mathrm{c}$ & $48.38 b$ & $48.67 b$ & 11.91 & $<0.00001$ \\
\hline FCRDE (kg/dz) & $1.443 \mathrm{c}$ & $1.613 \mathrm{ab}$ & $1.575 \mathrm{~b}$ & $1.638 \mathrm{a}$ & 6.42 & $<0.00001$ \\
\hline
\end{tabular}

BW: body weight; EW: egg weight; EC: energy conversion; EM: egg mass; FCRDE: conversion per dozen eggs. T1: Lohmann Brown commercial line + basal diet (100\%); T2: Embrapa 051 line + 93\% basal diet; T3: Embrapa 051 line + basal diet (100\%); T4: Embrapa 051 line $+107 \%$ basal diet. CV: coefficient of variation. P: probability. Means followed by different letters in the same row are significantly different by Tukey's test $(\mathrm{P}<0.01)$.

Compared with the first cycle, in the second, there was a numerical decrease in the weight of the Embrapa 051 birds that received less feed $(\mathrm{T} 2=$ 93\%), which showed that until then, the birds were not feeling the lack of feed, but from that moment on the treatment group started to show weight loss as well as a decrease in egg mass (g/bird/day), which was not observed during the first cycle. The other birds of the same line that received $100 \%$ and $107 \%$ basal diet did not show any difference $(\mathrm{P}>$ 0.05 ) in any of the three cycles.

Lohmann Brown hens, receiving 100\% basal diet presented higher laying rate in all evaluation cycles $(\mathrm{P}<0.05)$, while the Embrapa 051 line birds did not differ for feeding amount during first cycle. Harms et al. (2000) obtained similar results when feeding the same line with three different levels of metabolizable energy in the diets. The superiority of the Lohmann Brown line in terms of the laying rate in relation to the birds of the Embrapa 051 line persisted in the other cycles. As expected, during the second and third cycles, Embrapa 051 birds receiving less feed $(\mathrm{T} 2=93 \%)$ presented laying rate decrease, especially in the third production cycle $(\mathrm{P}<0.05)$.

In the first productive cycle, Lohmann Brown line (T1) presented the best energy conversion $(\mathrm{P}<0.05)$, which indicates that those birds consumed less calories to produce one gram of egg. However, they presented the worst energy conversions in the following cycles $(\mathrm{P}<0.05)$. In the second and third cycles, the Embrapa 051 birds receiving $93 \%$ basal diet showed the best energy conversion $(\mathrm{P}<0.05)$, while received the least amount of feed. This demonstrates that the birds of this treatment converted better the dietary energy into eggs, while those of the same line receiving $100 \%$ and $107 \%$ basal diet converted less efficiently energy into eggs and increased their body weight, as seen in Table 3 . The results 
obtained differ from those reported by Costa et al. (2004), who tested three different levels of metabolizable energy in the diets supplied to laying hens of the Lohmann Brown line, and found no significant difference for the feed conversion per gram of egg.

The birds of the Lohmann Brown line (T1) obtained the best feed conversion per dozen eggs (FCRDE) that was consistent and significantly lower in comparison to all Embrapa 051 treatments ( $\mathrm{P}<0.05)$. In the two previous cycles, this same treatment was statistically similar to that of the Embrapa 051 receiving 93\% basal diet. Embrapa 051 hens receiving $107 \%$ basal diet presented the worse FCRDE in the three cycles. However, in the third cycle, they did not differ significantly from the birds of the same line receiving 93\% basal diet (T2), which in turn did not differ from those receiving $100 \%$ basal diet $(\mathrm{P}<0.05)$. As the birds of the treatment 2 received less feed, with the progress of the cycles they started to demonstrate greater physical weakness and probably resulted in reduced FCRDE for the birds.

The results of internal egg quality variables in the three evaluated productive cycles are presented in Table 4. Yolk and albumen percentages presented a significant difference $(\mathrm{P}$ $<0.05)$ between treatments in all three cycles, where the percentage of yolk was higher in the eggs produced by the Embrapa 051 line.

Table 4. Internal egg quality produced by two laying breeds (E - Embrapa 051 and L - Lohmann Brown) subjected to different feeding programs in three productive cycles.

\begin{tabular}{|c|c|c|c|c|c|c|}
\hline \multirow{2}{*}{ Variables } & \multicolumn{6}{|c|}{ 1st cycle ( 25 - 28 weeks) } \\
\hline & T1 & $\mathbf{T 2}$ & T3 & T4 & CV (\%) & $\mathbf{P}$ \\
\hline$\%$ Yolk & $23.52 b$ & $25.50 \mathrm{a}$ & $24.98 \mathrm{a}$ & $25.09 \mathrm{a}$ & 8.31 & $<0.00001$ \\
\hline$\%$ Albumen & $66.88^{\mathrm{a}}$ & $65.66 \mathrm{~b}$ & $66.26 \mathrm{ab}$ & $65.99 \mathrm{ab}$ & 3.15 & 0.0092 \\
\hline $\mathrm{L}^{*}$ & 54.06 & 54.08 & 53.92 & 54.11 & 3.38 & 0.9405 \\
\hline$a^{*}$ & $-5.07 b$ & $-4.81 \mathrm{ab}$ & $-4.73 a b$ & $-4.49 a$ & 21.03 & 0.0170 \\
\hline$b^{*}$ & 33.78 & 34.52 & 34.42 & 34.85 & 7.02 & 0.0975 \\
\hline $\mathrm{C}$ & 34.17 & 34.87 & 34.76 & 35.16 & 6.81 & 0.1326 \\
\hline Color & 7.12 & 7.13 & 7.21 & 7.25 & 9.76 & 0.6721 \\
\hline YI & 0.42 & 0.42 & 0.42 & 0.43 & 8.42 & 0.3726 \\
\hline \multirow[t]{2}{*}{$\mathrm{HU}$} & 85.84 & 87.10 & 86.94 & 85.96 & 5.93 & 0.4110 \\
\hline & \multicolumn{6}{|c|}{ 2nd cycle (29 - 32 weeks) } \\
\hline$\%$ Yolk & $24.45 b$ & $26.58 \mathrm{a}$ & $26.33 \mathrm{a}$ & $26.08 \mathrm{a}$ & 7.27 & $<0.00001$ \\
\hline$\%$ Albumen & $65.95^{\mathrm{a}}$ & $64.65 b$ & $65.08 b$ & $65.09 \mathrm{~b}$ & 2.79 & 0.0012 \\
\hline $\mathrm{L}^{*}$ & 53.35 & 53.45 & 53.77 & 53.32 & 3.27 & 0.4617 \\
\hline$a^{*}$ & -4.92 & -5.08 & -5.25 & -5.11 & 25.18 & 0.5525 \\
\hline$b^{*}$ & 43.10 & 42.83 & 43.05 & 42.65 & 5.66 & 0.7211 \\
\hline $\mathrm{C}$ & 43.39 & 43.15 & 43.35 & 42.97 & 5.54 & 0.7106 \\
\hline Color & 7.84 & 7.8 & 7.71 & 7.88 & 7.49 & 0.3591 \\
\hline YI & 0.41 & 0.41 & 0.42 & 0.41 & 8.28 & 0.5967 \\
\hline \multirow[t]{2}{*}{ HU } & 82.29 & 84.18 & 83.96 & 83.64 & 6.21 & 0.8012 \\
\hline & \multicolumn{6}{|c|}{ 3rd cycle (33 - 36 weeks) } \\
\hline$\%$ Yolk & $24.68 b$ & $27.41 \mathrm{a}$ & $27.19 \mathrm{a}$ & $27.34 \mathrm{a}$ & 7.80 & $<0.00001$ \\
\hline$\%$ Albumen & $65.53^{\mathrm{a}}$ & $63.71 b$ & $64.15 b$ & $64.02 b$ & 3.13 & $<0.00001$ \\
\hline $\mathrm{L}^{*}$ & 53.60 & 53.64 & 53.46 & 53.69 & 3.27 & 0.8954 \\
\hline$a^{*}$ & -4.44 & -4.67 & -4.82 & -5.01 & 28.96 & 0.1252 \\
\hline$b^{*}$ & 40.99 & 40.56 & 40.26 & 40.05 & 6.95 & 0.2310 \\
\hline $\mathrm{C}$ & 41.26 & 40.85 & 40.58 & 40.39 & 6.23 & 0.2926 \\
\hline Color & 7.49 & 7.52 & 7.40 & 7.35 & 7.64 & 0.3103 \\
\hline YI & $0.37 \mathrm{~b}$ & $0.39 \mathrm{a}$ & $0.39 a$ & $0.39 \mathrm{a}$ & 7.50 & 0.0037 \\
\hline $\mathrm{HU}$ & 84.21 & 83.56 & 83.75 & 82.15 & 6.80 & 0.1900 \\
\hline
\end{tabular}

L*: luminosity; a*: red/green coordinate; b* yellow/blue coordinate; C: chroma; YI: yolk index; HU: Haugh unit. T1: Lohmann Brown commercial line + basal diet (100\%); T2: Embrapa 051line + 93\% basal diet; T3: Embrapa 051 line + basal diet $(100 \%)$; T4: Embrapa 051 line $+107 \%$ basal diet. P: probability. Means followed by different letters in the same row are significantly different by Tukey's test $(\mathrm{P}<0.01)$.

Scott and Silversides (2000) compared laying hens of two commercial lines at different ages and observed no significant difference between the lines in any of the egg quality variables. However, the authors state that albumen is the component that most influences egg weight. 
Similarly, Washburn (1990) states that there is a high correlation between egg weight and albumen percentage, which is confirmed in this study, since the Lohmann Brown line produced heavier eggs (in all cycles) and larger percentages of albumen (in the second and third cycles), in relation to those produced by the Embrapa 051 line under different feeding programs $(\mathrm{P}<0.05)$. On the other hand, the same author assures that there is a correlation between the weight of the shell and the percentage of yolk, which was not verified in the present study, in which the treatments with the highest percentages of yolk had the lowest percentages of shell (Embrapa 051 line).

Carvalho et al. (2007) compared four different lines of laying hens with a mean age of 29 weeks and did not detect a difference $(\mathrm{P}>0.05)$ between them regarding the percentage of yolk. Nevertheless, when applying different feeding programs for the same line, the variable did not differ between treatments. Therefore, the results corroborate those obtained in this study.

The yolk index behaved the same way as the yolk percentage, with lower values for the Lohmann Brown line receiving 100\% basal diet (only in the third productive cycle evaluated) and the other three treatments did not differ. This value obtained by the Lohmann Brown line in the third cycle (0.37) was the only one lower than that recommended to maintain the internal quality of the eggs, which is in the range of 0.39 to 0.45 (Eisen et al., 1962). As the weeks pass, the birds produce eggs with higher percentages of yolk, consequently, the yolk index decreases. This may be the explanation for the reduction in this variable to the result obtained by the Lohmann Brown line in the third cycle, since the birds of this line are precocious and may have presented this change in production earlier than the Embrapa 051 line.

The variables related to egg yolk color, both measurements with colorimetric fan and with digital colorimeter, showed no significant difference between the treatments $(\mathrm{P}>0.05)$. The exception was the first cycle, where the variable $\mathrm{a}^{*}$ was higher for the eggs produced by the Embrapa 051 line, receiving $107 \%$ basal diet and lower for the Lohmann Brown line. The values obtained for eggs produced by the Embrapa 051 line receiving 93 and $100 \%$ basal diet, respectively, treatments 2 and 3, were similar to each other and did not differ from any of the other two treatments. In the CIELAB space (color coordinates $\mathrm{L}^{*}, \mathrm{a}^{*}$ and $\mathrm{b}^{*}$ ), $\mathrm{a}^{*}$ is the coordinate that indicates the color trends from red to green (McLaren, 1976). According to this definition, negative values indicate tendency to green color. Thus, the color of the egg yolk produced by the Lohmann Brown line receiving $100 \%$ basal diet tended to the green and the eggs produced by the Embrapa 051 line, receiving 107\% basal diet, tended the least. The yolk color is influenced by diet and may vary according to the variety and quality of the feed provided, as well as the type and amount of carotenoids present (Hernández, 2001). At the end of the experiment, the birds suffered euthanasia and necropsy, and intestinal verminoses were found in several of them. This fact may explain, at least in part, the results obtained, since Brawner et al. (2000) and Tyczkowski et al. (1991) reported that the presence of parasites or intestinal infections may impair intestinal absorption and thus compromise the pigmentation of target tissues such as skin, feather and yolk.

The Haugh unit is considered a measure that expresses the egg quality, since it takes into account the height of the albumen thickness (Williams, 1992). According to the USDA (2006), high quality eggs are those that reach values of Haugh unit equal or greater than 72 . In the present study, no significant difference was detected for this variable between the eggs produced by the different lines and even by the Embrapa 051 line under different feeding programs. The eggs produced had Haugh units in the range of 82.1587.10 , therefore considered of high quality, regardless of the line or feeding program used.

The mean values, as well as the coefficient of variation and the probabilities of the external quality variables of the three productive cycles are shown in Table 5. All analyzed variables showed significant difference between the treatments.

The specific gravity is considered an indicator of egg shell quality, so it is possible to conclude that birds of the Lohmann Brown line receiving $100 \%$ basal diet produce eggs of better quality, since they produced eggs with the highest values for this variable in the three productive cycles $(\mathrm{P}<0.05)$. On the other hand, there was no difference in the specific gravity of eggs of the Embrapa 051 line (T2, T3, and T4) in any of the evaluated cycles ( $\mathrm{P}>0.05$ ), which demonstrates that this variable is more dependent on genetics than on nutrition. Nevertheless, when testing three feeding programs, this difference was not found.

The percentage and thickness of eggshell showed a behavior similar to that of specific 
gravity. The Lohmann Brown line showed significantly higher values than the Embrapa 051 line, whose treatments were not different from each other $(\mathrm{P}>0.05)$. In this study, a direct relationship between the percentage and the thickness of shell was registered, agreeing with results found by Olsson (1934), Hempe et al. (1988), and Hamilton (1982).

Table 5. External egg quality produced by two laying breeds (E - Embrapa 051 and L - Lohmann Brown) subjected to different feeding programs in three productive cycles

\begin{tabular}{|c|c|c|c|c|c|c|}
\hline \multirow{2}{*}{ Variables } & \multicolumn{6}{|c|}{ 1st cycle ( 25 - 28 weeks) } \\
\hline & T1 & $\mathbf{T} 2$ & T3 & $\mathbf{T 4}$ & CV $(\%)$ & $\mathbf{P}$ \\
\hline SG & $1084.5 \mathrm{a}$ & $1079.3 b$ & $1079.1 \mathrm{~b}$ & $1079.9 \mathrm{~b}$ & 0.50 & $<0.00001$ \\
\hline $\mathrm{ST}(\mu \mathrm{m})$ & $45.44^{\mathrm{a}}$ & $42.60 \mathrm{~b}$ & $42.22 b$ & $42.62 b$ & 6.96 & $<0.00001$ \\
\hline \multirow[t]{2}{*}{$\%$ shell } & $9.61^{\mathrm{a}}$ & $8.34 \mathrm{~b}$ & $8.77 \mathrm{~b}$ & $8.92 b$ & 8.12 & $<0.00001$ \\
\hline & \multicolumn{6}{|c|}{ 2nd cycle (29 - 32 weeks) } \\
\hline SG & $1081.9 \mathrm{a}$ & $1076.2 b$ & $1076.1 \mathrm{~b}$ & $1076.7 b$ & 0.48 & $<0.00001$ \\
\hline $\mathrm{ST}(\mu \mathrm{m})$ & $44.09^{\mathrm{a}}$ & $39.70 b$ & $38.97 b$ & $39.38 b$ & 10.30 & $<0.00001$ \\
\hline \multirow[t]{2}{*}{$\%$ shell } & $9.59^{\mathrm{a}}$ & $8.77 \mathrm{~b}$ & $8.61 b$ & $8.77 \mathrm{~b}$ & 7.83 & $<0.00001$ \\
\hline & \multicolumn{6}{|c|}{ 3rd cycle (33 - 36 weeks) } \\
\hline SG & $1085.9 \mathrm{a}$ & $1079.4 b$ & $1077.5 b$ & $1077.7 \mathrm{~b}$ & 0.55 & $<0.00001$ \\
\hline $\mathrm{ST}(\mu \mathrm{m})$ & $44.03^{\mathrm{a}}$ & $41.48 b$ & $40.42 b$ & $40.42 b$ & 7.13 & $<0.00001$ \\
\hline$\%$ shell & $9.79^{\mathrm{a}}$ & $8.88 \mathrm{~b}$ & $8.65 b$ & $8.65 b$ & 8.76 & $<0.00001$ \\
\hline $\begin{array}{l}\text { SG: specific gravity } \\
(100 \%) \text {; T2: Embrap } \\
\text { basal diet. P: probal } \\
(\mathrm{P}<0.01) \text {. }\end{array}$ & $\begin{array}{l}\text { iickness; } \\
93 \% \text { basa } \\
\text { followed }\end{array}$ & $\begin{array}{l}\text { efficient of } \\
\text { Г3: Embrap } \\
\text { ferent letter }\end{array}$ & $\begin{array}{l}\text { tion. T1: } \\
\text { line + ba } \\
\text { the same }\end{array}$ & $\begin{array}{l}\text { ann Brown } \\
\text { t }(100 \%) ; \mathrm{T} \\
\text { e significar }\end{array}$ & $\begin{array}{l}\text { nmercial } 1 \\
\text { Embrapa } 0 \\
\text { different }\end{array}$ & $\begin{array}{l}+ \text { basal die } \\
\text { line }+107 \% \\
\text { Tukey's tes }\end{array}$ \\
\hline
\end{tabular}

Stadelman (1977) reports that shells with a thickness of at least $33 \mu \mathrm{m}$ are $50 \%$ more likely to withstand transportation and normal handling in supermarkets, without suffering damage. In the present study, the birds of all treatments, in the three evaluated periods, produced eggs whose shell thickness presented results higher than this value, varying from 38.97 to $45.44 \mu \mathrm{m}$.

The variables related to shell quality were influenced more by genetics than by the feeding programs, since the three treatments with the Embrapa 051 line did not differ from each other $(\mathrm{P}>0.05)$ in any of the cycles evaluated for the variables of shell percentage, shell thickness and apparent density, with values always lower than those obtained by the Lohamm Brown line. Thus, it was evident that hens of the Lohamm Brown line produced eggs with better quality shells.

Akbar et al. (1983) and Kemps et al. (2006) also found a significant difference $(\mathrm{P}<0.05)$ in the variables related to shell quality when comparing different lines of laying hens. Nonetheless, Akbar et al. (1983) also evaluated the effect of diet and observed no influence on shell quality. This fact confirms the idea that the genetic improvement of laying hens over the years has focused more on increasing the rate of egg production and egg weight without paying the same attention to the other components of product quality, such as the shell (Curtis et al., 1985; Poggenpoel et al., 1996; Hocking et al., 2003).

In general, the Lohmann Brown line, already established in the market for several years, presents genetically a more consistent performance, showing results superior to the Embrapa 051 line regarding the laying rate, egg weight, and shell quality. Moreover, they are birds with lower body weight and so consume less feed.

On the other hand, the Embrapa 051 line showed the potential to produce well without the need to increase the amount of feed supplied beyond that recommended by the basic feeding 
program included in the guide of the Lohmann Brown line, used as a reference, despite being heavier hens than those of the Lohmann Brown line. They produced good egg quality based on the values obtained for yolk percentage and also with suitable values of Haugh unit.

\section{Conclusion}

In conclusion, Embrapa 051 lineage has the potential to produce good quality eggs, as long as it receives the same feeding program of the genetically established lineage.

\section{Conflict of Interest}

The authors declare that there is no conflict of interest.

\section{Ethics Committee}

The present experiment was conducted in an alternative egg farming system in southern Brazil, in the State of Santa Catarina, from January 2016 until November 2016. All procedures were carried out in agreement with the guidelines to the Animal Experimentation Ethics Committee under number 8469/2016.

\section{References}

ABPA. Associação Brasileira de Proteína Animal, 2016. Available: <http://abpabr.com.br/noticia>. Acess in: 08 July. 2016.

Akbar, M.K.; Gavora, J.S.; Friars, G.W.; Gowe, R.S. Composition of eggs by commercial size categories: Effects of genetic group, age, and diet. Poultry Science, 62(6): 925-933, 1983.

Barbosa, V.M.; Baião, N.C.; Mendes, P.M.; Rocha, J.S.; Pompeu, M.A.; Lara, L.J.; Martins, N.R. S.; Nelson, D.L.; Miranda, D.J.A.; Cunha, C.E.; Cardoso, D.M.; Cardeal, P.C. Avaliação da qualidade da casca dos ovos provenientes de matrizes pesadas com diferentes idades. Arquivo Brasileiro de Medicina Veterinária e Zootecnia, 64(4): 1036-1044, 2012.

Brawner, W.R.; Hill, G.E; Sundermann, C.A. Effects of coccidial and mycoplasmal infections on carotenoid-based plumage pigmentation in male house finches. The Auk, 117(4): 952-963, 2000.

Carvalho, F.B.; Stringhini, J.H.; De Moraes Jardim Filho, R.; Leandro, N.S.M.; Café, M.B.; De Deus, H.A.S.B. Qualidade interna e da casca para ovos de poedeiras comerciais de diferentes linhagens e idades. Ciência Animal

Brasileira, 8(1): 25-30, 2007.

Costa, F.G.P.; Souza, H.C.D.; Gomes, C.A.V.; Barros, L.R., Brandão, P.A.; Nascimento, G.A.J.D.; Santos, A.W.R.; Amarante Junior, V.D.S. Níveis de proteína bruta e energia metabolizável na produção e qualidade dos ovos de poedeiras da linhagem Lohmann Brown. Ciência e Agrotecnologia, 28(6): 1421-1427, 2004.

Curtis, P.A.; Gardner, F.A.; Mellor, D.B.A. Comparison of Selected Quality and Compositional Characteristics of Brown and White Shell Eggs I. Shell Quality. Poultry Science, 64(2): 297-301, 1985.

Eisen, E.J.; Bohre, B.B.; Mckean, H.E. The Haugh unit as a measure of egg albumen quality. Poultry Science. 41(1): 1461-1468, 1962.

Hamilton, R.M.G. Methods and factors that affect the measurement of egg shell quality. Poultry Science, 61(10): 2022-2039, 1982.

Harms, R.H.; Russell, G.B.; Sloan, D.R. Performance of four strains of commercial layers with major changes in dietary energy. The Journal of Applied Poultry Research, 9(4): 535-541, 2000.

Hempe, J.K.; Lauxwn, R.C.; Savage, J.E. Rapid determination of egg weight and specific gravity using a computerized data collection system. Poultry Science, 67(6): 902-907, 1988.

Hernandez, J.M. Stable pigmenting carotenoids: a new concept for Least Cost Pigmentation. Journal Animal Feed Science and Technology, 5(6): 43-47, 2001.

Hocking, P.M.; Bain, M.; Channing, C.E.; Fleming, R.; Wilson, S. Genetic variation for egg production, egg quality and bone strength in selected and traditional breeds of laying fowl. British Poultry Science, 44(3): 365373, 2003.

Kemps, B.J.; Govaerts, T.; De Ketelaere, B.; Mertens, K.; Bamelis, F.R.; Bain, M.M.; Decuypere, E.M.; Baerdemaeker, J.G. The influence of line and laying period on the relationship between different eggshell and membrane strength parameters. Poultry Science, 85(7): 1309-1317, 2006.

Lohmann do Brasil. Guia de manejo Lohmann Brown. São José do Rio Preto, 2011.

Mazzuco, H. Ovo: alimento funcional, perfeito à saúde. Revista Avicultura Industrial, 2: 1216, 2008. 
McLaren, K. XIII-The development of the CIE $1976\left(\mathrm{~L}^{*} \mathrm{a}^{*} \mathrm{~b}^{*}\right)$ uniform colour space and colour-difference formula. Coloration Technology, 92(9): 338-341, 1976.

Olsson, N. Studies on specific gravity of hen's eggs. A new method for determining the percentage of shell on hen's eggs. Leipzig: Otto Harrassowitz, 1934.

Poggenpoel, D.G.; Ferreira, G.F.; Hayes, J.P.; Du Preez, J.J. Response to long-term selection for egg production in laying hens. British Poultry Science, 37(4): 743-756, 1996.

Scott, T.A.; Silversides, F.G. The effect of storage and strain of hen on egg quality. Poultry Science, 79(12): 1725-1729, 2000.

Stadelman, W.J.; Cotterill, O.J. Egg science and technology. New York: Food Products Press, 1977.

Statistix 10. Analytical software PO Box 12185; Tallahassee, 2016.

Tyczkowski, J.; Schaeffer, J. L.; Hamilton, P. B. Measurement of malabsorption of carotenoids in chickens with pale-bird syndrome. Poultry Science, 70(11): 2275-2279, 1991.
USDA (United States Departament of Agriculture).

Egg grading manual, 2006. Available: $<$ https://www.ams.usda.gov/aboutams/programs-offices/livestock-poultry-seedprogram>. Acess in: 02 September. 2016.

Zumbado, M. La gravedad especifica para determinar la calidad del cascaron. Avicultura Profesional, 1(1): 8-10, 1983.

Washburn, K.E. Genetic variation in egg production. In: Crawford, R.D. (Ed.). Poultry breeding and genetics. New York: Elsevier. 1990. p.781-804.

Williams, K.C. Some factors affecting albumen quality with particular reference to Haugh unit score. World's Poultry Science Journal, 48(1): 5-16, 1992.

Wu, G.; Gunawardana, P.; Bryant, M.M.; Roland, D.A. Influence of dietary energy and antibiotic on performance, egg solids, and egg quality in Bovans White and Dekalb White hens. The Journal of Applied Poultry Research, 17(3): 323-330, 2008. 